\title{
Ergonomics curricula in Korean design colleges
}

\author{
Kyong-Hee Lee and Hong-In Cheng \\ Graduate School of Digital Design, Kyungsung University \\ 2472@dreamwiz.com, hicheng@,ks.ac.kr
}

\begin{abstract}
Human factors engineering has been taught in the design fields and considered as a necessary course for design students. We, ergonomists working with a design department, analyzed the current status of ergonomics curricula in the Korean design colleges. Sixty one percent of schools with design departments were offering ergonomics courses and most courses were electives. Comparatively more ergonomic courses were offered in industrial design and digital media departments. Ergonomic and human factors knowledge might not properly be acquired with this current status of the design curricula and systematic solutions should be considered and prepared for the future Korean designers.
\end{abstract}

Keywords: Ergonomics, Design education, Design curricula

\section{Introduction}

Ergonomics or human factors engineering is a study improving the quality of our living by designing, evaluating, redesigning usable system with considering human beings characteristics and enhancing efficiency, productivity, accuracy, and satisfaction of a system where human is included.

Design colleges started to involve human factors engineering in their curricula because design technology is closely related to ergonomics in designing and manipulating user-centered design. Ergonomic consideration for users can actually improve and add more competitive factors to the consumer products, interior design, interface design, etc. Ergonomics plays an important role in not only helping designers to understand physical, emotional, and cognitive features of human being but also supporting scientific research and design methodology. Human computer interaction can be usefully applied to environmental, industrial, fashion, furniture, and craft design.

Contemporary design is expanding its academic and practical boundary and being closely connected with adjacent studies such as engineering, management, and marketing. Although human factors engineering was introduced in the design field comparatively earlier than other related studies, designers do not usually have enough ergonomic knowledge to enhance their practical design.

We, ergonomists working with design department, studied the state of ergonomics curricula of Korean design colleges and found features of human factors in design colleges, and suggested adequate improvement of ergonomics curricula in design colleges.

\section{Research method}

In this study, 1) ergonomic classes were listed up first to know the status of human factors curricula by searching web sites of design colleges and 2) On-line and off-line questionnaires were prepared and design professionals and students were surveyed. 3) We also interviewed lecturers of ergonomic courses to know their education and teaching in detail.

In the survey, independent variables were school year, major, and experience of ergonomic classes for student respondents and academic background, major, employment history, and experience of ergonomic classes for the professionals respectively. Dependent variables were necessity of ergonomic knowledge and necessity of ergonomic courses for design colleges. Likert 5 scale was employed to measure respondents' understanding human factors curricula. Cross-tabulation and Mann-Whitney $U$ test were utilized to analyze the non-parametrically distributed survey data.

Better application and improvement of ergonomic education were then suggested by respondents. The summary of their ideas were also presented in this study to explain the statistical survey results. General study procedure was shown in Figure 1.

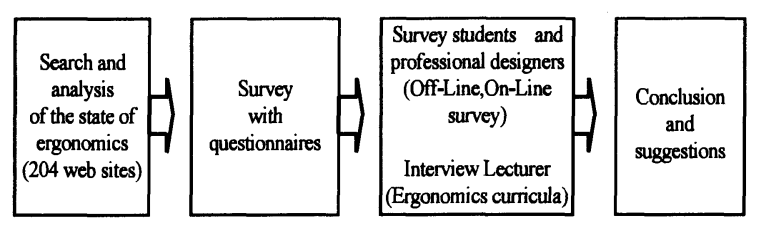

Figure 1. Procedure of the study

\section{Status of ergonomics curricula}

204 web sites of Korean universities registered in Korean Council for University Education were examined to study the curricula for 2 months in the autumn, 2005. Most universities had design related departments except national universities of education, religious universities, universities of technology, and maritime university. There were totally 120 universities where design related departments existed. Human factors related courses were included in the curricula of 73 universities and 93 departments. Fourteen universities were excluded in the study since their web sites did not support enough information about the curricula.

Ergonomic courses can be classified roughly into seven categories: human factors, interactive design, interface design, human sensitivity(kansei) engineering, usability engineering, artificial intelligence, and human behavior. Sixty two departments offered single ergonomic course, eighteen departments opened two courses, eight departments presented three classes, etc. (Figure 2). 


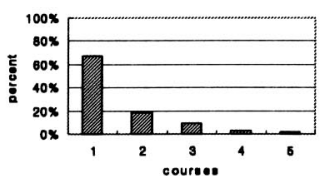

Figure2. Number of ergonomic courses in design colleges

Similar courses were grouped into a representative course. Human factors engineering was most common course title and offered by $42 \%$ of the departments and interactive design was offered in 33 departments, etc. (Table 1). Interface design handled more practical topics and interactive design was focusing on more theoretic studies. Students, designers, and lecturers thought interface design is more practical and interactive design is more theoretical.

Table 1. Status of Ergonomic courses in design colleges

\begin{tabular}{lcccccc}
\hline \multirow{2}{*}{ Title } & \multirow{2}{*}{ Department } & \multicolumn{6}{c}{ Grade } \\
\cline { 3 - 7 } & & 1 & 2 & 3 & 4 & Graduate \\
\hline Ergonomics (Human factors) & 50 & 1 & 17 & 10 & 1 & \\
\hline Interactive Design & 33 & 2 & 7 & 5 & 1 \\
\hline Interface Design & 21 & 3 & 9 & 2 & \\
\hline Sensitivity(Kansei) Engineering & 15 & 2 & 4 & 4 & \\
\hline Usability Engineering & 2 & & & 1 \\
\hline AI* & $2^{*}$ & & & \\
\hline Human Behavior* & $1^{*}$ & & & \\
\hline * Offering grades of Human behavior and AI were not confirmed on web sites
\end{tabular}

Specifically named courses titles were also used to represent studying areas such as ergonomics and furniture design, human body and apparel, interior and ergonomics. Objectives of the courses were to understand the characteristics of human and develop more efficient, safer, and easier design. Interaction and $\mathrm{HCI}$ courses were offered in interactive design field and their objectives were to understand interaction between various media and human. Human's sensitivity, cognition, GUI, and usability were also treated in the classes. Interface design was taught to help students understand more efficient communication methods and increase the ability to improve the environment.

User interface design, industrial(product) user interface design, and design interface were included in the curriculum. Material sensitivity engineering, fashion sensitivity, sensitivity practice were course names for human sensitivity(Kansei) engineering and statistical methods to quantifying sensitivity and emotion and its application were commonly taught. Usability engineering, artificial intelligence(AI), and human behavior were also included in the design department curricula.

Table 2 shows that industrial(product) design and digital media departments offered more ergonomics courses.

Table 2. Status of Ergonomics courses due to major

\begin{tabular}{lcccccc}
\hline Course & $\begin{array}{c}\text { Product } \\
\text { Design }\end{array}$ & $\begin{array}{c}\text { Digital } \\
\text { Media }\end{array}$ & $\begin{array}{c}\text { Visual } \\
\text { Design }\end{array}$ & $\begin{array}{c}\text { Environment } \\
\text { Design }\end{array}$ & $\begin{array}{c}\text { Fashion } \\
\text { Design }\end{array}$ & Total \\
\hline Human Factors & 31 & 2 & 1 & 9 & 1 & 44 \\
\hline Interactive Design & 11 & 14 & 9 & & & 34 \\
\hline Interface Design & 12 & 8 & 1 & & & 21 \\
\hline Sensitivity Design & 8 & 1 & 2 & 3 & 6 & 20 \\
\hline Usability Eng. & & 2 & & & & 2 \\
\hline AI & & 1 & & & & 1 \\
\hline Human Behavior & 1 & & & 12 & 1 \\
\hline Total & 62 & 29 & 13 & 12 & 17 \\
\hline
\end{tabular}

\section{Survey results}

We surveyed students from five universities in Busan, Korea and Kyungnam region to study their understandings of ergonomics curricula. Off-line and on-line surveys were also performed of nationwide design students and professionals from December, 2005 to January, 2006.

64 students (male: 25 , female: 39 ) and 9 professionals (male: 4 , female: 5) participated in the survey. Student respondents can be categorized into 9 freshmen (14\%), 17 sophomores (27\%), 19 juniors (30\%), and 19 seniors (30\%) and professionals were classified into 1 community college graduates (11\%), 5 university graduates $(30 \%)$, and 3 graduate school graduates (34\%). Professional respondents were categorized according to their work experience: $1-2$ year (33\%), 3-5 year (11\%), and 5-10 year (56\%). Table 3 grouped participants according to their majors and ergonomic class experience.

Table 3. Classification of survey participants

\begin{tabular}{llcc}
\hline Classification & & Student & Professional \\
\hline Major & Industrial design & 25 & 3 \\
\cline { 2 - 4 } & Digital media design & 22 & 1 \\
\cline { 2 - 4 } & Visual design & 3 & 3 \\
\cline { 2 - 4 } & Environment design & 8 & 2 \\
\cline { 2 - 4 } & Fashion design & 4 & \\
\cline { 2 - 4 } & Etc. & 2 & 5 \\
\hline Class & Yes & 32 & 4 \\
\cline { 2 - 4 } experience & No & 32 & \\
\hline
\end{tabular}

\subsection{Necessity of ergonomic knowledge}

Cross-tabulation was employed to analyze the usage extent of ergonomic knowledge in the process of practical design on the job and class. There was significant difference in necessity understanding due to the majors of students $(p<.001)$. Both students and designers, however, felt ergonomic knowledge would be essential for designers. No significant difference was detected among professionals about the necessity of ergonomics (Table 4). When total data was analyzed, significant different understanding was observed for the necessity of ergonomic knowledge.

Table 4. Cross-table for the necessity of ergonomics curricula

\begin{tabular}{llccc}
\hline \multicolumn{2}{c}{ Independent variable } & Pearson chi-square & df & P-value \\
\hline \multirow{2}{*}{ Student } & School year & 40.797 & 9 & .290 \\
\cline { 2 - 5 } & Major & 38.469 & 15 & $.001^{* *}$ \\
\hline \multirow{2}{*}{ Professional } & Schooling & 2.640 & 4 & .620 \\
\cline { 2 - 5 } & Work Experience & 6.840 & 4 & .145 \\
\cline { 2 - 5 } & Major & 7.800 & 6 & .253 \\
\hline \multirow{2}{*}{ Total } & Occupation & 2.708 & 3 & .439 \\
\cline { 2 - 6 }${ }^{*} \alpha=.05,{ }^{* *} \alpha=.01$ & 43.984 & 15 & $.000^{* *}$ \\
\hline
\end{tabular}

Figure 3 shows that most professional designers felt ergonomic knowledge is very required for designers except visual designers. Industrial design students especially believed human factors knowledge is very important and necessary.

Industrial, digital media, and environmental designers evaluated that ergonomic knowledge is essential in their practical job and design projects. The necessity of ergonomic knowledge according to the experience of taking human factors classes was approved by Mann-Whitney $U$ test. There was significant difference in understanding of necessity of ergonomic classes between students had taking ergonomic classes and other students $(\mathrm{P}<.02)$. Most students, however, felt human factors knowledge is especially required for better design (Figure 4). 

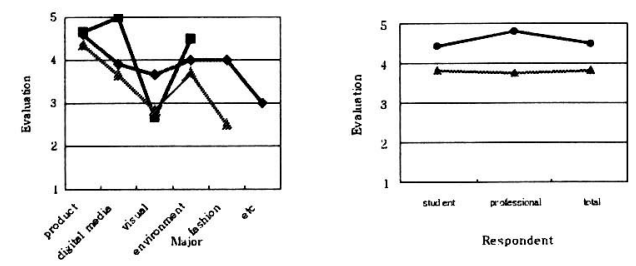

- : student, a : professional. $\triangle$ : tota

- : experienced, $\Delta$ : not experienced

Figure 3. Necessity of ergonomic knowledge Figure 4. Necessity of ergonomic classes

Even though statistical test showed no significant difference in the necessity between employed respondents according to the class experience, most professional designers answered ergonomic knowledge is essential for more usable design.

Respondents, agreed with the necessity of human factors classes, were asked to report the reason and the results are summarized in Table 5 .

Table 5. Necessity of ergonomic knowledge

\begin{tabular}{ll}
\hline Students & - Design exists for human and better environment \\
& - Ergonomic application adds value to design \\
& - Human factors helps to design products in detail \\
& - Human factors should be considered for the interface design \\
& - To design not just good looking but easy to use \\
& - To respond various user requirements \\
- Functional products are designed with ergonomic knowledge & - Ergonomics is basic knowledge designers must have \\
- Currently issued universal design requires human factors knowledge \\
\hline Professional & - Design is for human \\
designers & - Human uses design (design target is human) \\
& - More convenient design is possible \\
-Ergonomics supplements design methodology
\end{tabular}

Both student and employed designers explained that design exists for human being and human-centered design is a famous and approved solution to design for human. Ergonomic knowledge may help to design better, more user-friendly, and more efficiently. Some respondents reported what users want can be easily accepted and reflected on design with human factors knowledge. Ergonomic design is also believed as a new trend for popular and convenient design.

\subsection{Necessity of ergonomics curricula}

The necessity of ergonomic courses according to grade, major, and work experience was examined by cross-tabulation. It was detected that students judged significantly differently about the necessity of ergonomic courses according to the school year $(\mathrm{p}<.03)$ and major $(\mathrm{P}<$.02) (Table 6). Freshmen's understanding the necessity of ergonomic courses was significantly less than other students $(\mathrm{p}<.001)$. Industrial design students felt that ergonomic classes are significantly more required than other major students.

Table 6. Chi-square table for the necessity of ergonomic class

\begin{tabular}{llccc}
\hline \multicolumn{2}{l}{ Independent variable } & Pearson chi-square & $\mathrm{df}$ & P-value \\
\hline \multirow{2}{*}{ Student } & School year & 22.837 & 12 & $.029^{*}$ \\
\cline { 2 - 5 } & Major & 36.710 & 20 & $.013^{*}$ \\
\hline \multirow{2}{*}{$\begin{array}{l}\text { Professional } \\
\text { designer }\end{array}$} & Schooling & 4.500 & 6 & .609 \\
\cline { 2 - 5 } & Work experience & 10.800 & 6 & .095 \\
\cline { 2 - 5 } & Major & 10.125 & 9 & .340 \\
\hline \multirow{2}{*}{ Total } & Occupation & 4.211 & 4 & .378 \\
\cline { 2 - 5 } & Major & 41.955 & 20 & $.003^{* *}$ \\
\hline${ }^{*} \alpha=.05,{ }^{* *} \alpha=.01$ & & &
\end{tabular}

${ }^{*} \alpha=.05,{ }^{* *} \alpha=.01$
Industrial design students most highly recognized the necessity of ergonomic classes but visual design student did not think ergonomic classes are required (Figure 5). Professional designers evaluated ergonomic classes significantly more important than students did. Especially digital media workers believed ergonomics is essential subject for design colleges.
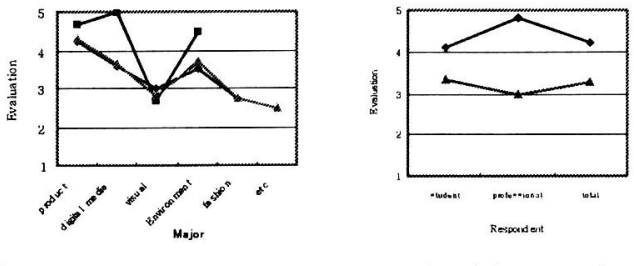

: student, $\mathbf{a}$ : professional, $\boldsymbol{\Delta}$ : total Figure 5. Necessity of ergnomics cuniculaofferings

Class experience affected respondents' answers about the necessity of ergonomic class offerings. Students $(p<.001)$ and professional designers $(p<.016)$ having experience taking ergonomic classes felt ergonomics courses were significantly more required than no experienced respondents and insisted that ergonomic class should be included in design college curricula (Table 7).

Table 7. Necessity of ergonomic class due to the experience (Mann-Whitney U test)

\begin{tabular}{lcc}
\hline Classification & Mann-Whitney U & P-value \\
\hline Student & 281.000 & $.001^{* *}$ \\
\hline Profession designer & .500 & $.016^{*}$ \\
\hline Total & 286.500 & $.000^{* *}$ \\
\hline${ }^{*} \alpha=.05, \quad{ }^{* *} \alpha=.01$ & &
\end{tabular}

Although there was some difference according to the experience of the class, all participants reported human factors class is very important and should be offered in design colleges.

Interesting fact was experienced professional designers stronger insisted the necessity of ergonomic courses than experienced students. Not experienced professional designers, however, less felt the need of ergonomic courses than students.

Professional designers were also asked to select as many as ergonomic courses which were most frequently utilized on the job and interface design was believed the most useful class (33\%). Human factors, human sensitivity (kansei) engineering, usability engineering, and artificial intelligence were assessed very required topics.

In the questionnaire, respondents were asked to check as many as courses which should be obligatory subjects. 55 participants $(86 \%)$ selected more than one course as required subjects. $25 \%$ respondents answered interface design is worth to be an obligatory subject (Table 8). 33\% professional designers recommended interface design is the most useful and required on the job. Ergonomics, interactive design, human sensibility engineering, usability engineering, artificial intelligence were evaluated most utilized for the practical design job by $17 \%$ of respondents. 
Table 8. Subjects considered obligatory

\begin{tabular}{lcc}
\hline Course & Student & Professional \\
\hline Ergonomics & 14 & 2 \\
\hline Interactive Design & 23 & 2 \\
\hline Interface Design & 24 & 3 \\
\hline Human Sensitivity Engineering & 12 & 2 \\
\hline Usability Engineering & 9 & 2 \\
\hline Artificial Intelligence & 2 & 2 \\
\hline Design and Human behavior & 7 & 1 \\
\hline Etc. & 4 & - \\
\hline None & 6 & - \\
\hline
\end{tabular}

\subsection{Attendance of ergonomic courses}

It was known from the survey that $34 \%$ of students and $25 \%$ of employed designers among participants took interactive design and interface design courses. Ergonomics (14\% of students) and usability engineering (17\% of professionals) were also popular courses to designers

It was reported that students, not taking ergonomic classes, wanted to take interface design $(25 \%)$, human sensitivity engineering (17\%), ergonomics (17\%), interactive design $(17 \%)$, human behavior $(10 \%)$, and usability engineering ( $9 \%)$.

The experienced respondents were asked to describe required improvements in ergonomics courses and the answers are introduced in Table 10. Students answered that the brief concept and necessity of classes are should be understood first and designers practice is more important than theories. Most respondents reported practical teaching is the most required point in human factors related classes.

Table 10. Required improvements in ergonomics curricula - necessity of ergonomics (curricula) should be understood first - practical class is more required - various case-studies are desirable.

-more experienced practitioners should teach - more courses should be open -one semester is not enough to acquire ergonomic knowledg - practical class is required

Professional Designers -practical teaching is preferable

- various courses and in-depth study is desirable

\subsection{Ergonomics curricula in design colleges}

We visited three universities to inquire about ergonomics curricula in design colleges. Ergonomic course lecturers or related professors were interviewed about the actual teaching and the summarized results are given in Table 11.

Table 11. Ergonomics curricula state in design colleges

\begin{tabular}{|c|c|c|c|}
\hline & A University & B University & C University \\
\hline $\begin{array}{l}\text { current } \\
\text { courses }\end{array}$ & $\begin{array}{l}\text { - digital media des } \\
\text { project } \\
\text { - digilog design }\end{array}$ & $\begin{array}{l}\text { n- interaction design } 1,2 \\
\text { - ergonomics } \\
\text { - HCI }\end{array}$ & - ergonomics \\
\hline contents & $\begin{array}{l}\text { - test } \\
\text { - term paper } \\
\text { - term design } \\
\text { project }\end{array}$ & $\begin{array}{l}\text { - test } \\
\text { - term design } \\
\text { project } \\
\text { - seminar } \\
\end{array}$ & $\begin{array}{l}\text { - test } \\
\text { - soft mock up } \\
\text { - team project }\end{array}$ \\
\hline \multicolumn{3}{|c|}{ problem - students do not have- lack of references } & - lack of references \\
\hline $\mathrm{s}$ & knowledge at all & $\begin{array}{l}\text { - lack of lecturers } \\
\text { - quantitative study and } \\
\text { survey is not familiar to } \\
\text { design students }\end{array}$ & $\begin{array}{l}\text { - lack of students' } \\
\text { dscientific background } \\
\end{array}$ \\
\hline $\begin{array}{l}\text { Lecturer } \\
\text { 's major }\end{array}$ & $\begin{array}{l}\text { - visual design }+ \\
\text { interactive design }\end{array}$ & $\begin{array}{l}\text { - design } \\
\text { (ergonomic designer) }\end{array}$ & - industrial design \\
\hline
\end{tabular}

\section{Conclusion and Discussion}

Convergent study is recently more required in the design field because of the trends and transition of times. Engineering, management, and psychology have been introduced and applied in design college curricula. We, ergonomists, investigated ergonomics curricula in design colleges and suggested some improvements in the study.

Seven types of ergonomic courses are being offered in design colleges and titles of courses are common e.g., ergonomics, interaction design, etc. or specifically named to represent the characteristics of department e.g., fashion aesthetic engineering, ergonomics and furniture design, human body and apparel, etc..

Our future designers may have not enough ergonomic knowledge and understanding of users because 73 universities offer ergonomic courses among 120 universities teach ergonomic courses. In addition, although ergonomic subjects are taught, most courses are elective. It can be strongly suggested that at least one ergonomic course should be obligatory in design colleges. Most designers recommended interface design as a required subject.

We would like to suggest three plans to improve ergonomics curricula and more efficient education from the perspectives of students and departments. First, students must know just looking-good design is not enough to satisfy users. Human-centered design can be an alternative solution since it's based on the understanding physical and cognitive characteristics and limits of human. Second, department and lecturer are required to understand academic background of students. They are not oriented scientific procedures, methods, and subjects. Students can have ergonomic intuition and ability to apply the knowledge into their real design when more practical ergonomic case-studies are introduced in the class. Third, more familiar course titles and course descriptions are should be employed to explain ergonomics to design-major students. Easier text book and references containing more examples should be provided and more experienced practitioners participate in teaching.

\section{References}

[1] Park, J. S. Paradigm change and specialization of Design Education, A truth Forum, 459-482, 2004

[2] Lee, S. J., Cha, S. J., Min, K. W., Kim, J.W., Joo, W. J., A Study on Interdepartment-Interdisciplinary Collaboration Research, 2005 Korean Society of Design Science Fall Conference, 202-203, 2005

[3] Oh, Keun-Jae, Acus of Reversion and escape of Design Education in Korea, Speech Notes of 2005 Korean Society of Design Science Fall Conference \& International Conference on Design Education and Research, 48-51, 2005

[4] Jung, E. S., Developmental Perspectives of Curricula in the Ergonomics, IE Magazine, 53-58, 2002

[5] Korean Council for University Education http://www.kcue.or.kr 